\title{
CIRCUITOS ESPACIAIS DA PRODUÇÃO E NOVAS DINÂMICAS DO TERRITÓRIO
}

\author{
circuits of spacial production and the new dynamics in the territory
}

\author{
Denise Cristina Bomtempo* \\ Eliseu Savério Sposito**
}

\begin{abstract}
Resumo
Fazer a leitura do território do ponto de vista do desenvolvimento das atividades econômicas, no período da globalização, é uma tarefa complexa. Novas dinâmicas estão postas e diferentes configurações notadas. É preciso identificar os agentes, entender os processos e interpretar as relações que influenciam nas decisões que reestruturam a organização territorial. Com base nesse conjunto de transformações, este artigo procura analisar as dinâmicas recentes da produção industrial do ramo de alimentos de consumo final. Pauta-se na investigação dos circuitos espaciais da produção e dos círculos de cooperação e tem como perspectiva realizar uma leitura empírica de inúmeras transformações na cidade de Marília/SP, articulando os estudos das interações espaciais com os da cidade média, no contexto das determinações impostas pelo meio técnico-científico-informacional.
\end{abstract}

Palavras-Chave: Circuitos espaciais da produção, círculos de cooperação, dinâmica territorial, indústria de alimentos e cidade média.

\begin{abstract}
Read of the territory from the point of view of development of economic activities in the period of globalization is a complex task. New dynamics are posed and different configurations noted. You need to identifyagents, understand the process and interpret the relationships that influence decisions to restructure the territorial organization. Based on this set of transformations, this article analyzes the recent dynamics of industrial production in the food sector of final consumption. Tariff on research space circuits of production and cooperation circles and has the prospect to do some reading empirical many changes in the city of Marília / SP, linking the study of spatial interactions with medim-sized cities, in the context of determinations imposed by the technical andscientific-informational.
\end{abstract}

Key words: Circuits of production space, circles of cooperation, territorial dynamics, food industry and medium-sized cities.

\begin{abstract}
Résumé
Lire le territoire du point de vue du développement des activités économiques dans la période de la mondialisation est une tâche complexe. Des nouvelles dynamiques sont posées et différentes configurations sont notée. Vous avez besoin d'identifier les agents, comprendre les processus et d'interpréter les relations qui influencent les décisions de restructurer l'organisation territoriale. Basé sur cette série de transformations, cet article analyse la dynamique récente de la production industrielle dans le secteur alimentaire de la consommation finale.Tarif sur les circuits de la recherche spatiale de la production et les cercles de coopération et a la perspective de faire une lecture empirique de nombreux changements dans la ville de Marília / SP, reliant l'étude des interactions spatiales avec la ville moyenne, dans le contexte des déterminations imposées par milieu techniques-scientifiques-informationnel.
\end{abstract}

Mots-Clés: Circuits d'espace de production, des cercles de coopération, la dynamique territoriale, l'industrie alimentaire et la ville moyenne.

(*) Doutora em Geografia pelo Programa de Pós Graduação em Geografia da Universidade Estadual Paulista Júlio de Mesquita Filho, Presidente Prudente e Docente na Pós Graduação em Geografia da Universidade Estadual do Ceará - Av. Paranjana, 1700, CEP: 60.740-903, Fortaleza (CE), Brasil. Tel: (+55 85)3101.9762 - denibomtempo@hotmail.com

(**) Bolsista Produtividade do CNPq e Prof. Dr. da Pós-Graduação em Geografia da Universidade Estadual Paulista Júlio de Mesquita Filho, Presidente Prudente - Rua Roberto Simonsen, 305. CEP: 19060-900, Presidente Prudente (SP), Brasil. Tel/Fax: (+55 18) $32295660 / 32218212$ - essposito@gmail.com 


\section{INTRODUÇÃO}

O recente desenvolvimento das tecnologias de transporte e comunicação vem comprimindo as distâncias e acelerando as velocidades, ao mesmo tempo em que proporciona mudanças importantes na leitura da organização do território. Tais mudanças, de acordo com Santos (1999), estão inseridas num contexto de transição do meio técnico para o meio técnico-científico-informacional, onde a informação passa a ser a chave da produção e da extração de uma mais-valia cada vez tornada global. O processo resulta em profunda reestruturação espacial que se manifesta, entre outros, na forma desigual com que alguns territórios se inserem nos circuitos produtivos da economia capitalista e da produção industrial.

A expansão dos investimentos, sobretudo de grandes conglomerados empresariais e a instalação de novos equipamentos vinculados à economia mundo, redefine o papel desempenhado pelos territórios na divisão territorial do trabalho. Um caminho importante, escolhido para entender muitas das transformações espaciais em destaque, é analisar as dinâmicas territoriais a partir da distribuição dos estabelecimentos e dos arranjos dos circuitos espaciais da produção e dos círculos de cooperação , propostos por Santos (1986), Santos e Silveira (2001) e Arroyo (2001). Através dessas interações espaciais, conseguimos entender as dinâmicas e os movimentos materiais e imateriais do presente, ou seja, é possível investigar o "uso do território". Além disso, também podemos multiplicar nossas escalas de análise, pois os circuitos e seus respectivos círculos integram territórios que muitas vezes não são contíguos, mas que a partir de uma configuração formada por redes organizacionais, materializam-se enquanto unidade.

Outro ponto importante a ser considerado com a emergência do meio técnico-científico-informacional, em especial na realidade econômica e urbana brasileira, é que o desenvolvimento das atividades econômicas e produtivas industriais não se restringe mais à aglomeração metropolitana; pelo contrário, cidades de diferentes portes estão sendo inseridas num circuito espacial de produção e consumo. A nova conformação dos circuitos espaciais e dos círculos de cooperação não tem mais como se afirmar sem a inserção da cidade média como um recorte essencial de leitura da reestruturação econômica do território.

É neste contexto que propomos a leitura da atividade industrial de alimentos de consumo final no âmbito da geografia das novas redes e fluxos. Cada vez mais, a cidade média assume um papel proeminente no conjunto articulado dos circuitos espaciais e dos círculos de cooperação da produção de alimentos e a organização o território vai ganhando complexidade em função do novo quadro que se desenha.

Para dar conta da discussão em pauta, este texto encontra-se estruturado em três partes, além desta introdução e das considerações finais. Na primeira parte, discorremos sobre a configuração do ramo industrial alimentício de consumo final inserido no contexto do processo de organização espacial da produção no Brasil. Na segunda parte, preocupamo-nos em apresentar a origem e os atuais processos de reestruturação territorial e produtiva do referido ramo na cidade de Marília/SP. Por fim, na terceira parte do artigo, apresentamos a configuração dos circuitos espaciais da produção e dos círculos de cooperação das pequenas, médias e grandes empresas industriais em Marília, quando a discussão será levada às considerações finais.

\section{A CONFIGURAÇÃO DO RAMO ALIMENTÍCIO DE CONSUMO FINAL E OS PROCESSOS DE REESTRUTURAÇÃO TERRITORIAL E PRODUTIVA NO BRASIL}

A aceleração das velocidades e o imperativo da competitividade, características da globalização da economia, imprimem o conceito de "tempo rápido" nas relações entre os sujeitos e as instituições. Estes são cada vez mais induzidos ao cumprimento de ritmos e normas que alteram as formas de produção e consumo no contexto da produção do espaço, o que só é possível através de uma alteração nos padrões de organização do território e na articulação entre os lugares. 
De acordo com Santos (2000, p. 28), torna-se real o conhecimento instantâneo do acontecer do outro e, em função disso, materializa-se uma "convergência dos momentos". No entanto, poucos são capazes de utilizar essa "solidariedade" em seu favor, mas quem consegue pode usufruir do mesmo momento a partir de inúmeros lugares e de múltiplos lugares a partir de um só momento, sempre de "forma concatenada e eficaz" (SANTOS, 2000, p. 28).

No âmbito da produção e circulação de mercadorias, o processo de globalização faz emergir outra organização econômica, desta vez ligada à capacidade de criação de novos sistemas espaciais que repercutem no grau de concentração das empresas; na velocidade dos deslocamentos; e no alcance espacial dos processos produtivos. Novos circuitos de redes tendem a ser criados, modificando a funcionalidade e o conteúdo das cidades e das regiões, que são alterados em razão de novas imposições competitivas da racionalidade tecnológica.

Ao tratar dos ramos produtivos industriais no contexto supracitado, Martinelli Jr. (1999) afirma que cada ramo produtivo, para permanecer no mercado, seguem padrões gerais no que concerne aos processos de reestruturação das linhas de produção e, ao mesmo tempo, possui padrões de concorrência, definidos por "um conjunto de formas que se revelam dominantes no espaço de competição" (p. 4). Essas formas concorrenciais são reconhecidas pelos processos de fusão e aquisição; inovação tecnológica; novos padrões de contratação da força de trabalho; investimentos em propaganda e publicidade; ampliação e inovação das linhas de produtos; articulação com os investimentos financeiros; e novas lógicas de integração territorial.

Além disso, essas empresas estão usando com muito mais desenvoltura certas estratégias territoriais de distribuição da produção, abandonando grandes centros produtores tradicionais, sobretudo na grande metrópole capitalista, e transferindo suas fábricas para lugares onde os ritmos da produção industrial são recentes ou tinham pouca importância há algumas décadas.

As empresas industriais do ramo alimentício de consumo final, para se fortalecerem no mercado competitivo global e ampliarem o seu poder de ação no espaço, recorrem a todas essas estratégias. São mudanças que passam pela reorganização interna da empresa, principalmente no que concerne à gestão, à criação, às inovações tecnológicas e às formas de contratação da força de trabalho. Além disso, as empresas articulam novas tecnologias de produção ao uso fragmentado do território, sobre o qual se montam arranjos estabelecidos em rede, capazes de aproveitarem as muitas vantagens das verticalidades do espaço.

Mas o destaque no que tange à penetração desse ramo na nova lógica competitiva, como aponta Martinelli Jr. (1999), é que essas empresas se comportam como "tomadoras de inovações", assumindo tendências diferenciadas do ponto de vista produtivo e territorial, sobretudo por relocalizar linhas de produção inteiras e incorporar relevante "progresso técnico", desenvolvido em articulação com outros ramos da produção industrial de alta tecnologia, a exemplo do químico e do farmacêutico.

Desse modo, na esteira da globalização da economia e dos valores de reprodução socioespacial, o aprofundamento técnico associado à mudança do perfil da população mundial em relação ao consumo de alimentos garantiu maior complexidade à produção de comida industrializada. Diante disso, não podemos mais caracterizar o ramo alimentício apenas como um ramo tradicional da indústria de transformação, pois as inovações se fazem presentes e são frutos de pesquisas científicas que objetivam, entre outros, o desenvolvimento de novos produtos de maneira acelerada e a expansão dos mesmos pelos mais diversos lugares do mundo.

Isso implicou em mudanças consideráveis neste ramo de produção da indústria, alterando formas de inserção no mercado, a ampliação da produção e do consumo e novas estratégias de localização das unidades produtivas. No Brasil, em fins do século XX e na primeira década do século XXI, presenciamos um aumento considerável do número de estabelecimentos e de empregos ocupados neste ramo. Em 1985, havia no país 21.805 estabelecimentos, segundo dados da RAIS . Já em 1995, a partir de um desdobramento dos gêneros e ramos do grande setor Alimentos e Bebidas, o total alcançou 17.539 só para a quantidade de estabelecimentos produtores de Alimentos. 
Enquanto isso, em 2007, houve redução nestes números de estabelecimentos, com o total chegando a 17.261. Todavia, no que tange aos números de empregos formais gerados entre 1995 e 2007 houve considerável ampliação, pois a quantidade total no primeiro ano era de 2.303 .120 e no segundo ano passou para 2.791.660, isto é, um aumento de 488.540 empregos.

Atualmente, de acordo com a Associação das Indústrias de Alimentação (ABIA), o faturamento das empresas produtoras atinge R $\$ 291,6$ bilhões. Entre os anos de 2008 e 2009, mesmo em período de crise financeira internacional, esses índices só se ampliam, computando um aumento considerável. Como informa a ABIA:

O setor fechou 2009 com faturamento em torno de R \$ 290 bilhões. Para se ter ideia do significado de sua contribuição para a produção industrial e a balança comercial do país, as exportações totais brasileiras foram US\$ 152,99 bilhões e as importações US\$ 127,64 bilhões, com saldo positivo de US $\$ 25,35$ bilhões. As vendas externas de alimentos industrializados totalizaram US $\$ 30,86$ bilhões e as importações US\$ 3,16 bilhões, gerando superávit de US\$ 27,70 bilhões, ou seja, US\$2,35 bilhões acima do saldo da balança comercial brasileira (Entrevista ao Presidente da ABIA, Edmundo Klotz, in: Anuário da ABIA, 2009/2010, p. 3).

Entre as empresas do setor alimentício que participaram de maneira mais intensa no total do faturamento dos anos citados, destacam-se aquelas do ramo de derivados de carne $(23,68 \%)$; café, chá e cereais (13,3\%); açúcares (12,3\%); laticínios (11,8\%); óleos e gorduras (11,8\%); derivados de trigo $(7,7 \%)$; derivados de frutas e vegetais $(6 \%)$; diversos - sorvetes, snacks, temperos $(6,2 \%)$; chocolate, cacau e balas ( $4 \%)$; desidratados e supercongelados $(2,3 \%)$ e conservas de pescados $(0,9 \%)$.

Do conjunto analisado, destacaremos a produção de derivados de trigo (biscoito) e o segmento de chocolates, cacau e balas. A escolha se deve ao fato de que, segundo a ABIA, à exceção desses ramos, os demais são incluídos na produção agroindustrial, o que foge aos interesses de um trabalho interessado na produção industrial propriamente dita, inserida no contexto das transformações territoriais e produtivas do presente.

Segundo a Revista Super Varejo, entre as grandes empresas (líderes de venda) de biscoitos que atuam no território brasileiro, quatro pertencem a grupos empresariais de capital externo, são elas: 1) Kraft Foods Incorporation, cujo capital de origem é norte-americano e no Brasil a empresa possui seis fábricas ; 2) Parmalat S/A, com capital italiano e localizada, no Brasil, em Jundiaí/SP; 3) Grupo Danone S/A, pertencente a investidores da França, da Itália e da Espanha e com unidades produtivas em São Paulo/SP e Caldas Novas/MG no Brasil; e, por fim, 4) Nestlé S/A, cujo capital é suíço e com unidade produtiva de biscoitos localizada na cidade de Marília/SP.

No que tange às empresas mais importantes de capital nacional, merecem destaque a Marilan S/A e a Bauducco LTDA, de capital paulista, e a M. Dias Branco S/A, cuja origem do capital é cearense. Os estados de Pernambuco, Rio de Janeiro, Paraná e Santa Catarina também possuem empresas relevantes no mercado de biscoitos, mas a capacidade de distribuição dos seus produtos por todo o Brasil é limitada, o que as deixam com menor poder de negociação.

Em relação às empresas de chocolates, derivados de cacau, balas e aperitivos sólidos, de acordo com a Revista Varejo, as cinco maiores em vendas na escala do território brasileiro são a Pepsico Corporation (EUA); a Yoki S/A (Brasil - SP); a Fritex LTDA (Brasil - SP); a Dori LTDA (Brasil - SP) e a Iracema LTDA/Kraft Food (Estados Unidos e Inglaterra). Deste conjunto, a Pepsico Corporation apresenta-se como líder em vendas nas "áreas de atuação " selecionadas e delimitadas pela revista. Quanto às demais empresas, a Yoki S/A apresenta-se em segundo lugar em todas as "áreas" brasileiras, exceto no Distrito Federal, Goiás e Mato Grosso do Sul; a Fritex se afirma em terceiro lugar em todo o território nacional; a Dori LTDA está em quarto, destacando-se em vendas no interior de São Paulo, Paraná, Santa Catarina e Rio Grande do Sul; e a Iracema LTDA ocupa a quinta posição, concentrando seu mercado nos estados de Minas Gerais, Espírito Santo e interior do Rio de Janeiro. 
O fato relevante no contexto da distribuição espacial de todas essas empresas sobre o território nacional, é que o ramo de produção de alimentos de consumo final confirma uma discussão já levantada por Santos acerca de um crescimento econômico relativamente maior do "interior modernizado em relação à metrópole", principalmente no que tange ao estado de São Paulo (SANTOS, 2009, p. 73). Essa capacidade que as regiões do interior paulista têm de crescer economicamente mais que o centro metropolitano, pelo menos do ponto de vista relativo, pode ser vista pela distribuição dos ritmos da produção industrial em cidades como Marília, São José do Rio Preto, Sorocaba, Campinas etc.

No conjunto das empresas produtoras de alimentos de consumo final, a ser destacado neste artigo, constatamos uma diversidade do ponto de vista da origem do capital e da localização das unidades produtivas pelas diversas regiões do estado, mas verificamos que há empresas que possuem suas sedes em cidades que não fazem parte da principal região industrial paulista e outras que migraram desta grande área metropolitana, confirmando um movimento de relocalização que só é possível dentro do contexto das novas conformidades territoriais do período técnico-científico.

O caso de Marília, na região oeste de São Paulo, é o mais emblemático de todos. O centro urbano se afirma pela capacidade de reunir e desenvolver investimentos locais, ao mesmo tempo em que atraem capitais externos, entre eles os de origem nacional e internacional, mesmo sendo uma cidade considerada média na rede urbana do estado e localizando-se a $443 \mathrm{~km}$ da capital.

Assim, as empresas industriais alimentícias de consumo final instaladas na cidade de Marília são responsáveis por grande parte da produção dos biscoitos fabricados no território brasileiro, um conjunto que destaca a Marilan S/A, maior produtora nacional; a Dori LTDA, com grande produção e distribuição de chocolates; e a expressiva Nestlé S/A, que no coração do centro urbano mariliense, fabrica todas as linhas de biscoitos consumidos no território brasileiro e atende também países localizados nos continentes americano, europeu, africano e asiático.

Marília, desse modo, se insere no contexto da reestruturação industrial e produtiva do estado de São Paulo e do Brasil exatamente pela sua participação efetiva enquanto nó de uma ampla rede produtora de alimentos que articulam escalas espaciais diversas, responsável por integrar circuitos de produção e círculos de cooperação dentro e fora do território. Vejamos a seguir as origens e as principais características a destacar a cidade de Marília como importante centro produtivo.

\section{ORIGEM E CARACTERÍSTICAS DO RAMO ALIMENTÍCIO DE CONSUMO FINAL EM MARÍLIA/SP}

A atividade industrial em Marília, cidade sede da Décima Primeira Região Administrativa do estado de São Paulo, é anterior ao processo de desconcentração industrial iniciado na metrópole paulistana em 1970. Entre os anos de 1940 e 1960, os gêneros fabricados (máquinas agrícolas, calçados, vestuário e alimentos) pelas indústrias no município destinavam-se a atender ao mercado local e regional. Já a produção das agroindústrias de capital nacional e internacional destinava-se a atender o mercado brasileiro e os Estados Unidos, Japão e países europeus.

No ramo alimentício, a primeira fábrica de balas instalada na cidade data do ano de 1945 .

Santo Barion, filho de imigrantes italianos, instala, em 1945, junto com seus filhos, a Fábrica de Balas Cristal, que tinha como equipamento inicial dois tachinhos em fogo a lenha direto, uma pedra de mármore, um cilindro manual e uma mesa, onde trabalhavam dez moças embrulhando as balas a mão. Nessa época, como conta um dos fundadores, as balas fabricadas em São Paulo, pela Lacta, Pan, Falchi e outras empresas menores, dificilmente chegavam a Marília, o que vai permitir o crescimento rápido da empresa. Em fins de 1946, os Barion compram um prédio na rua XV de Novembro, com área de $250 \mathrm{~m} 2$, o que permite a diversificação para a produção de balas de goma, com a contratação de um técnico vindo da Lacta. Também em 1947 são admitidos dois vendedores para atuarem na Sorocabana, ampliando a área de vendas. Em 1950, chegam as primeiras máquinas embrulhadoras e a fábrica é 
novamente ampliada, mudando-se para um prédio maior adquirido de uma fiação de seda desativada (MOURÃO, 1994, p. 82).

Baseado nos estudos de Mourão (1994) e Bomtempo (2010), afirmamos que a origem da atividade industrial em Marília está atrelada à formação das atividades econômicas locais; aos investimentos dos imigrantes italianos e japoneses que se estabeleceram na cidade e se tornaram agentes da atividade industrial; à situação geográfica do município, em especial devido à distância da metrópole paulistana; e a disseminação de um "savoir-faire" adquirido pelos trabalhadores da indústria alimentícia, que depois de atuarem como funcionários, "montaram" o seu próprio negócio e aproveitaram o conhecimento adquirido na fábrica em que trabalharam.

Depois de um período inicial de consolidação, os microinvestimentos se expandiram e a atividade industrial gradativamente ampliou o seu número de estabelecimentos e de funcionários, fenômeno desencadeado, sobretudo, a partir do fim da década de 1970. Desde então, a tendência à abertura de novos empreendimentos se confirmou e a atração de capital proveniente de fora do município deu-se de maneira muito mais efetiva, o que tornou Marília um centro de convergência para os investimentos ligados à produção de alimentos.

Entre os anos de 1980 e 1990, a cidade reafirma essa capacidade de concentrar e atrair unidades produtivas e o aglomerado que resulta desse processo criam novas e importantes economias de escala, consolidando um centro de produção alimentar destacado não só no estado de São Paulo, mas em todo Brasil. De acordo com os dados da Fundação Seade (2007), referentes à economia das Regiões Administrativas paulistas,

a fabricação de alimentos e bebidas é a atividade industrial que mais se destaca na RA de Marília, tanto no valor adicionado como na geração de emprego. Por esse motivo, o município, sede da região, recebe o título de capital nacional do alimento (FUNDAÇÃO SEADE, 2007, p. 4).

Atualmente, há em Marília, 57 estabelecimentos industriais produtivos instalados do ramo alimentício de consumo final, sendo 28 microempresas, 17 pequenas, sete médias e cinco grandes. $\mathrm{O}$ total de empregos diretos alcança o número de 5.605 e a massa salarial envolvida é de $\mathrm{R} \$$ 5.667.085,00, representando um salário médio de R\$1.011,00.

As empresas desse ramo instaladas no município podem ser classificadas em dois grandes grupos: a) as originárias de capital local; b) as originárias de capital externo (nacional e internacional).

As empresas originárias de capital local são aquelas cujos investimentos provêem do excedente acumulado na agricultura ou em outras atividades econômicas urbanas, como os serviços. Elas têm portes diferenciados, sendo que as pequenas atuam apenas em escala local e regional; enquanto as médias e grandes negociam com mercados nacionais e internacionais, não sem realizar estratégias de reestruturação territorial e produtiva para consolidar suas ações de expansão.

No caso específico dessas medidas de reestruturação é preciso destacar mudanças no processo de produção mediante a gestão e utilização de novas tecnologias; a separação das unidades de produção e de gestão no território; a subcontratação da força de trabalho; a geração de novos produtos fabricados com tecnologia renovada; o investimento em setores de propaganda e marketing; e ainda, o cumprimento de normatizações estabelecidas por órgãos de fiscalização dos produtos alimentícios de influência internacional.

Quanto às empresas de capital externo, temos a presença de empreendimentos que se instalaram em Marília somente depois dos anos de 1980, cuja composição dos capitais envolve agentes mais diversificados, muitas vezes um produto das fusões e aquisições comuns aos mercados nacionais e internacionais. Podemos destacar duas empresas nesse rol, uma de capital proveniente de fora do país, tradicional na produção de biscoitos (Nestlé S/A); e a outra originária da região metropolitana de São Paulo (Yoki Alimentos S/A de São Bernardo do Campo), responsável pela produção de confeitos de amendoim, doces e salgados. 
De acordo com informações obtidas em trabalho de campo, reunimos um conjunto de informações que possibilita uma leitura ampla e sintética da organização industrial em Marília, pelo menos no que concerne ao ramo de alimentos de consumo final.

Primeiramente, constatamos que essas empresas são especializadas na produção de biscoitos de farinha de trigo e de polvilho, chocolates, amendoim e derivados, temperos, molhos, pipocas, doces, castanhas trituradas, recheios, balas, pirulitos e gomas. Também são responsáveis por empregar 5.983 trabalhadores de forma direta, sendo que deste total, 4.675 trabalham no processo produtivo e 1.308 trabalham na gestão, apoio logístico, pesquisa e desenvolvimento.

Em relação ao porte (MTE/RAIS, 2007), verificamos que 61,53\% são classificadas como microempresas, pois possuem de 0 a 19 funcionários formais; 7,69\% são pequenas empresas (20 a 99 funcionários); 19,23\% são médias, já que possuem de 100 a 499 funcionários; e 11,53\% compõem o conjunto das grandes empresas, possuindo acima de 500 empregados formais.

Verificamos também que $57,69 \%$ do total investiram em linhas de produção com compra de novos equipamentos; enquanto $19,23 \%$ adquiriram equipamentos novos, mas ainda utilizam os antigos; $11,53 \%$ renovaram totalmente as máquinas e equipamentos e descartaram os antigos; e $11,53 \%$ não realizaram investimentos na aquisição de novas máquinas e equipamentos.

Como é comum constatar, são as maiores empresas que detém a tecnologia mais avançada, enquanto as menos expressivas compram máquinas usadas ou negociam equipamentos cujo aparato técnico não é considerado renovado. Do total de empresas que usam máquinas automáticas no processo produtivo, $57,69 \%$ reúnem equipamentos manuais, 32,69\% trabalham com máquinas computadorizadas e $9,69 \%$ não utilizam mais do que tecnologia simples na fabricação dos produtos.

Grande parte dessas empresas, no espaço urbano de Marília, está instalada em cinco diferentes zonas industriais. Todavia, algumas delas extrapolam essa organização territorial e espalham-se pelo tecido urbano da sede do município, sobretudo no Bairro Jardim Santa Antonietta, onde a presença de duas rodovias estaduais (SP-333 e SP-294) e uma rodovia federal (BR-153) permite melhor fluidez e articulação da produção com outras parcelas do espaço.

Tal distribuição respeita uma lógica fundamentada no porte da unidade produtiva, na qual as maiores fábricas são exatamente aquelas instaladas próximas aos grandes eixos de escoamento da cidade. Bons exemplos para o caso citado são os da Marilan S/A e da Dori LTDA, que atualmente encontram-se ao lado das rodovias estaduais, mas, no passado, ocupavam amplos terrenos do espaço intraurbano, o que implica em deslocamento em função de melhor demanda logística, entre outros.

Ao respeitar a ordem supracitada, as empresas consideradas de médio porte assumiram um arranjo organizacional no espaço que priorizou a oferta de incentivos e a montagem de certa infraestrutura pelo poder público, selecionando para a instalação as áreas planejadas para reforçar a aglomeração de unidades produtivas. Neste caso, zonas industriais pré-concebidas se afirmaram e seus efeitos de atração pela via de vantagens competitivas formaram centros de produção, frequentemente conhecidos como "distritos industriais". Ao todo, como já informado, são cinco "distritos" em Marília, a reunir principalmente médias e algumas pequenas empresas.

Foge às duas regras de ocupação expostas, a estratégia de localização industrial dos menores estabelecimentos, isto é, micro e pequenas fábricas, que não necessitam de ampla área de ocupação nem atendem as expectativas do Estado para atraírem incentivos fiscais e de infraestrutura. $\mathrm{O}$ fato é que são empresas que geralmente não estão formalizadas e sua rotatividade no volume de produção e na contratação de trabalhadores é freqüente, o que as estimulam a ocuparem áreas no espaço intraurbano procurando aproveitar baixos preços de aluguel em bairros periféricos ou centrais.

Uma atenção especial deve ser dada ao caso da Nestlé S/A, empresa multinacional de expressiva produção, com grande planta industrial e que movimenta intenso fluxo de pessoas e veículos, mas está localizada no anel central da cidade, desconsiderando o congestionamento urbano do centro de Marília. É uma escolha determinada, principalmente, pela estrutura já montada de uma fábrica de biscoitos, pois a chegada da Nestlé está associada à aquisição da Beatrice Food Corporation S.A. (antiga Airilam LTDA) em 1989, que no local já dispunha de galpão e amplo terreno para expansão 
de área construída. Foi fundamental para os interesses da empresa suíça continuar no mesmo local da unidade incorporada, notadamente porque pôde aproveitar sua centralidade e ao mesmo tempo erguer novos galpões sem maiores custos adicionais. A tendência à deseconomia de aglomeração não foi confirmada nesta escolha locacional, pois a Nestlé não só ampliou sua estrutura como transferiu as linhas de produção de biscoito de outras unidades do país para essa fábrica.

Marília, portanto, dispõe de um importante centro industrial de produção de alimentos, mesmo não ostentando posição de comando na rede urbana paulista. Longe de apresentar a funcionalidade de um centro urbano de influência direta metropolitana ou de se colocar como uma cidade que regem os rumos das forças econômicas do estado, no âmbito da produção industrial do ramo de alimentos seu papel é decisivo, porquanto demonstra expressiva participação nos circuitos espaciais produtivos e nos círculos de cooperação. Como cidade média, só possui essa relevância devido às suas características regionais, mas também pela sua aptidão de se inserir como um "espaço luminoso" no arranjo territorial e produtivo atingido pelas novas determinações do meio técnico-científico-informacional.

Marília é exemplo de que as centralidades urbanas e produtivas estão sendo redefinidas no estado de São Paulo e no Brasil e que as transformações advindas das imposições tecnológicas e produtivas pedem uma leitura diferenciada do espaço no contexto da articulação entre sujeitos, objetos e movimentos.

\section{OS CIRCUITOS ESPACIAIS DA PRODUÇÃO DAS EMPRESAS INDUSTRIAIS ALIMENTÍCIAS INSTALADAS EM MARÍLIA/ SP}

Para entender se a atividade industrial contribui para dinamização territorial e a ampliação dos papéis da cidade média na divisão territorial do trabalho, tomamos como referencial as discussões realizadas por Sobarzo (2008). Para este autor, além de considerar a condição de intermediação da cidade média, é preciso, no período técnico científico, qualificar essa condição.

As cidades médias no contexto do conjunto articulado de redes e funcionalidades urbanas, já não podem mais ser analisadas do ponto de vista das simples relações estabelecidas com seu entorno, pois a densidade técnica e informacional possibilitou incorporá-las em circuitos produtivos mais complexos que articulam uma gama maior de lugares e agentes, ampliando suas atividades e papeis desempenhados na divisão territorial do trabalho. Como mapear esses processos e entender o conteúdo dessas mudanças de maneira inter e multiescalar?

Uma das possibilidades, de acordo com Santos (1986), Santos e Silveira (2001), Elias (2007), Silveira (2007) e Arroyo (2008), é a análise do território fundamentada nos circuitos espaciais da produção e dos círculos de cooperação, principalmente quando complementada com a discussão dos circuitos da economia urbana (SANTOS, 2004). O estudo dos circuitos espaciais da produção nos permite entender como se configuram as relações no âmbito de escalas interurbanas, que na maioria das vezes, conformam-se entre agentes que atuam a partir das muitas verticalidades do espaço. Por outro lado, a investigação das atividades dos circuitos da economia urbana, permite-nos entender como estão distribuídas as atividades na escala intraurbana, onde existem agentes que atuam tanto a partir das verticalidades supracitadas, como através de velhas e novas horizontalidades espaciais.

O trabalho com os circuitos espaciais da produção e os círculos de cooperação, no âmbito da indústria, permite-nos reconhecer as articulações estabelecidas entre os agentes e os lugares de aquisição de matéria-prima, gestão, produção, distribuição e consumo. Por outro lado, compreender a configuração dos círculos e circuitos da produção e dos circuitos da economia urbana nos possibilita avançar na discussão que reconhece a ampliação de papeis desempenhados pela cidade média, diferente do que é posto por estudos tradicionais de hierarquização urbana.

A cidade média, no período técnico científico simboliza o lugar das desigualdades e contradições, próprias da produção e organização do espaço capitalista que gera, agora em nível global, circuitos superiores e inferiores (atrelados) em cidades de diferentes portes e localizações. Essa 
análise reforça nossas preocupações, que não perpassa pela elaboração de um conceito de cidade média, embora reconheçamos a importância dessa tarefa, mas pretende discutir até que ponto as relações de inter e multiescalaridade sob a perspectiva das atividades econômicas do ramo industrial alimentício se fazem presentes além de cidades localizadas na escala da metrópole. Vejamos como se configuram esses arranjos no contexto da indústria de alimentos de consumo final em Marília.

\section{As micro e pequenas empresas industriais}

As micros e pequenas empresas industriais alimentícias de consumo final instaladas em Marília são, em sua maioria, de capital local, mas também temos exemplos de unidades produtivas oriundas de fora do município. O conjunto de articulações de insumo/produto e as interações espaciais desenvolvidas nas mais diversas escalas possibilitam uma interpretação do alcance dos circuitos espaciais e dos círculos de cooperação dessas empresas.

São informações que chegam a um nível de detalhamento expressivo, mas que contribuem para o olhar ampliado sobre a articulação cidade/região e região/país, sempre numa perspectiva que considere o dinamismo dos movimentos em tempos de globalização da economia. Como resultado, a leitura da cidade média e o seu arranjo no espaço geográfico, entendido como um meio técnico-científico-informacional, ganha abrangência.

Em Marília, as interações e circuitos tecidos por essas micros e pequenas empresas demonstram a complexidade das redes estabelecidas. No que diz respeito, por exemplo, a aquisição de matéria-prima e insumos (Figura 1), feita pelas indústrias desse porte, podemos perceber que predominam relações com municípios localizados no estado de São Paulo, principalmente aqueles relativamente próximos a Marília, como Novo Horizonte e Presidente Prudente (açúcar); Pompéia (corantes); Herculândia (óleos); Bastos e São José do Rio Preto (ovos e chocolates); Maracaí, Garça e Arujá (embalagens); Tupã e Quintana (amendoim, pasta de amendoim, óleos e embalagens); Penápolis e Ocauçu (farinhas); Bauru (uniformes); Ourinhos e Ubirajara (uniformes e polvilho); São Pedro do Turvo (óleos); Cândido Mota (farinha de trigo); Lins (embutidos, aromas e gás liquefeito de petróleo) e Anhumas (molho de soja). Mas municípios mais distantes também negociam sua produção industrial com essas empresas, a exemplo de São Paulo (uniformes, essências, corantes, aromas, glicose, embalagens e molho de soja); Jaboticabal (polvilho azedo); Jundiaí e Sorocaba (ovo líquido) e Votorantim (embalagens).

Vale ressaltar que no próprio município de Marília muitos insumos também são adquiridos, principalmente chocolates, frutas secas, farinha de trigo, farinha de milho, queijos, carnes, legumes, temperos, ovos, tomate seco, leite, e embutidos. No caso específico do amendoim, que é um produto muito utilizado por produtores locais, $100 \%$ é adquirido em municípios inseridos na região administrativa de Marília.

Além dos municípios do estado de São Paulo, verificamos que as matérias-primas e os insumos utilizados na produção das micro e pequenas empresas são provenientes de Jaraguá do Sul/SC (corantes); Sertanópolis/PR (lecitina de soja, farinha de mandioca e gorduras); Vitória/ES (castanhas e frutas secas); Cascavel/PR (farináceos); Cambará/PR (confeitos); Arapongas/PR (gordura vegetal); Laranjeira/PR (aromas); Hortolândia/PR (aromas); Taubaté e Torres/RS (embalagens); Goiânia/GO (polpa de tomate, canjica, sal, óleos vegetais e embalagens); Maringá/PR (farinha, sal e embutidos); Curitiba/PR (embutidos, amidos modificados); Uraí/PR (alho) e Mossoró/RN (sal).

As máquinas e equipamentos utilizados são fabricados em vários municípios do estado de São Paulo, tais como: Garça, São Bernardo do Campo, Cubatão, Piracicaba, Sertãozinho, Ourinhos, Guarulhos, Ribeirão Preto e Americana. Além disso, outros produtos chegam de Santa Catarina, Paraná e até de outros países, a exemplo de Portugal e Itália.

Os serviços relacionados à assistência de máquinas e equipamentos são realizados por empresas terceirizadas de Marília ou por profissionais autônomos do próprio município. Mas algumas dessas pequenas empresas também apresentam trabalhadores qualificados que se responsabilizam por tal atividade. 
Já o transporte dos produtos costuma ser realizado com veículos próprios da empresa (caminhões, peruas e motocicletas). Outras mercadorias, no entanto, são distribuídas por firmas subcontratadas e quando isso acontece, elas têm sede na própria cidade de Marília, mas também em Ourinhos/SP e Londrina/PR. Também alguns produtos são transportados pelo próprio cliente, que realiza compra direta na empresa.

As vendas dos produtos fabricados por essas empresas industriais são realizadas diretamente entre fabricante e comprador, por vendedores representantes da empresa, e ainda por revendedores. Entre os revendedores, destacam-se os doceiros que compram produtos das empresas alimentícias e negociam na própria cidade, em bairros da periferia e em municípios da região. Esses doceiros dirigem-se até a empresa para comprar mercadorias de acordo com as vendas, portanto, não trabalham com estoques.

Quanto à comercialização, verificamos que os principais compradores, além dos doceiros, são pequenos estabelecimentos comerciais $(34,61 \%)$, tais como lojas de produtos baratos importados, lanchonetes, bares e restaurantes, mercados de até dois check-outs, mercearias, atacadistas, rotisseries, e lojas de conveniência. 11,53\% dessas compras são feitas por redes de supermercados de Jaú/SP e de Marília/SP e 7,69\% dos produtos são comprados por outras empresas produtoras, o que implica em dizer que a prática de subcontratação também entre as unidades produtivas é comum. Por fim 3,84\% do que é negociado é feito através de estratégias de venda "porta a porta", o que confirma ainda certa precariedade na comercialização dos produtos e uma dependência junto aos estabelecimentos pertencentes ao circuito inferior da economia urbana.

Destacamos ainda outros serviços subcontratados pelas unidades produtivas de micro e pequeno porte em Marília, tais como assessoria jurídica, contabilidade, segurança e vigilância, seleção e treinamento de mão de obra, consultoria e limpeza predial.

Um fato curioso deve ser salientado. Os responsáveis pelas micro e pequenas empresas entrevistados durante a pesquisa de campo em Marília, afirmaram que a relação das fábricas com associações e sindicatos é quase nula, notadamente porque os custos mensais para o associado são altos e eles não dispõem "de tempo para participar de reuniões que discutem assuntos que estão fora da nossa realidade. Somos tão pequenos que não entendemos o que muitas vezes é falado, então é melhor ficar de fora" (Entrevista com responsável pela empresa de confeitos de amendoim - Distrito Industrial do Bairro Jardim Santa Antonietta, 2009).

As médias empresas

As empresas consideradas médias a atuarem na produção industrial alimentícia de Marília se diferenciam das pequenas principalmente quanto à origem do capital (de origem local e de fora de São Paulo e do Brasil), ao número de trabalhadores e ao volume de produção. São, principalmente, unidades produtivas de confeitos de amendoim, balas, gomas e chocolates e todas elas se localizam nos "distritos industriais" montados pelo poder público, com destaque para aquele localizado no Bairro Jardim Santa Antonietta, ao norte da sede municipal.

Articulam também com municípios e regiões numa escala muito mais abrangente, confirmando circuitos espaciais e círculos de cooperação mais amplos. É possível afirmar que esses estão configurados de maneira mais complexa em relação aos das micros e pequenas. Os lugares e regiões envolvidos na aquisição de matérias-prima e insumos, na contratação de serviços, na distribuição e comercialização de mercadorias etc., não se limitam à escala local e estadual paulista, predominando interações com outros estados (Figura 2).

Como resultado de pesquisa de campo, constatamos que as matérias-primas e insumos comprados são provenientes dos seguintes municípios: 1) em São Paulo temos Novo Horizonte, Tarumã, Paraguaçu Paulista, Promissão e Maracaí (fornecedores de açúcar); Tupã, Herculândia, Quintana e Pompéia, (abastecedores de amendoim, aromatizantes e corantes); Rio Claro (abastecimento de mel); e São Paulo (glucose, amidos, aromatizantes, corantes e produtos físico-químicos). 2) em outros 


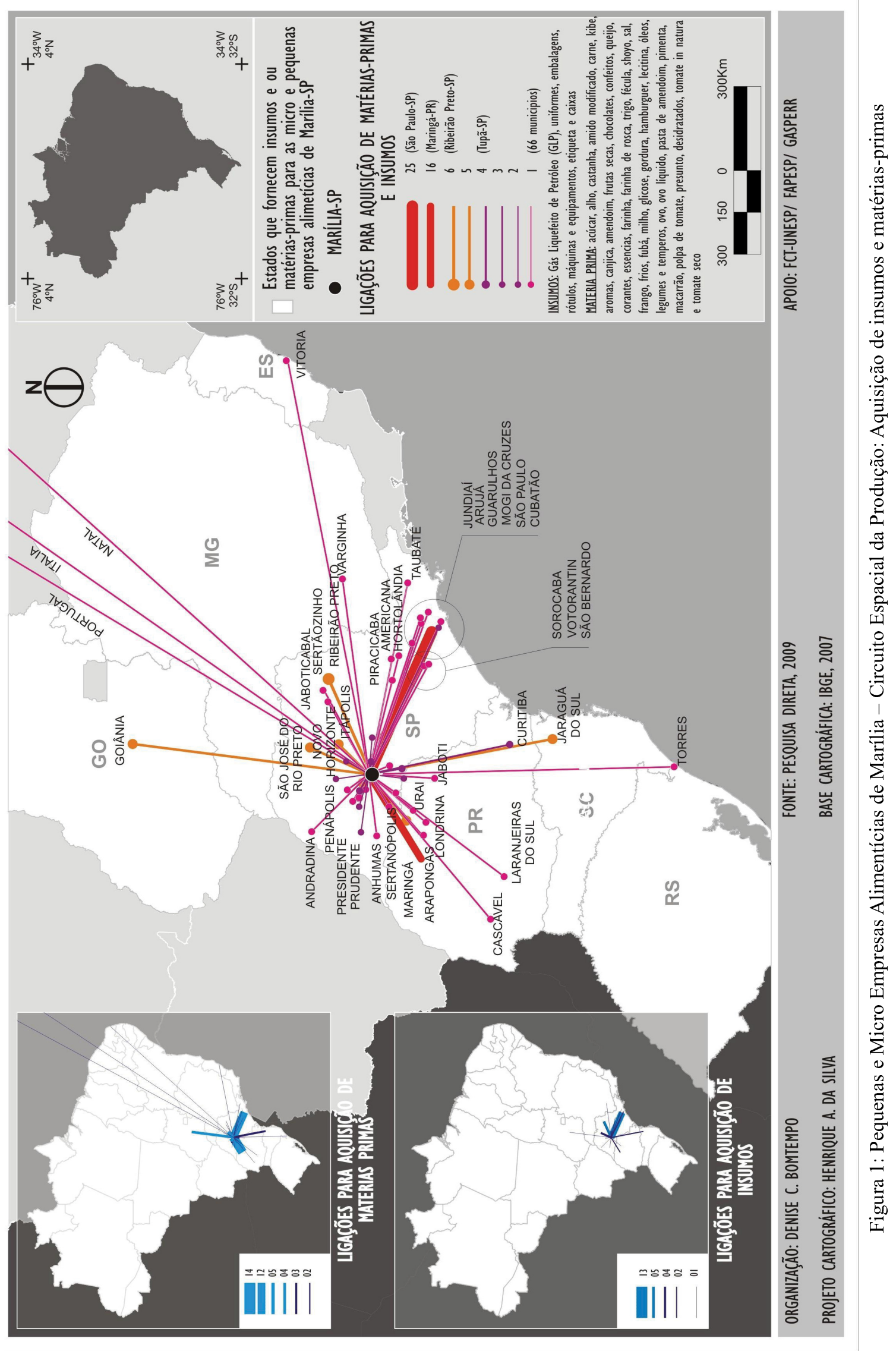




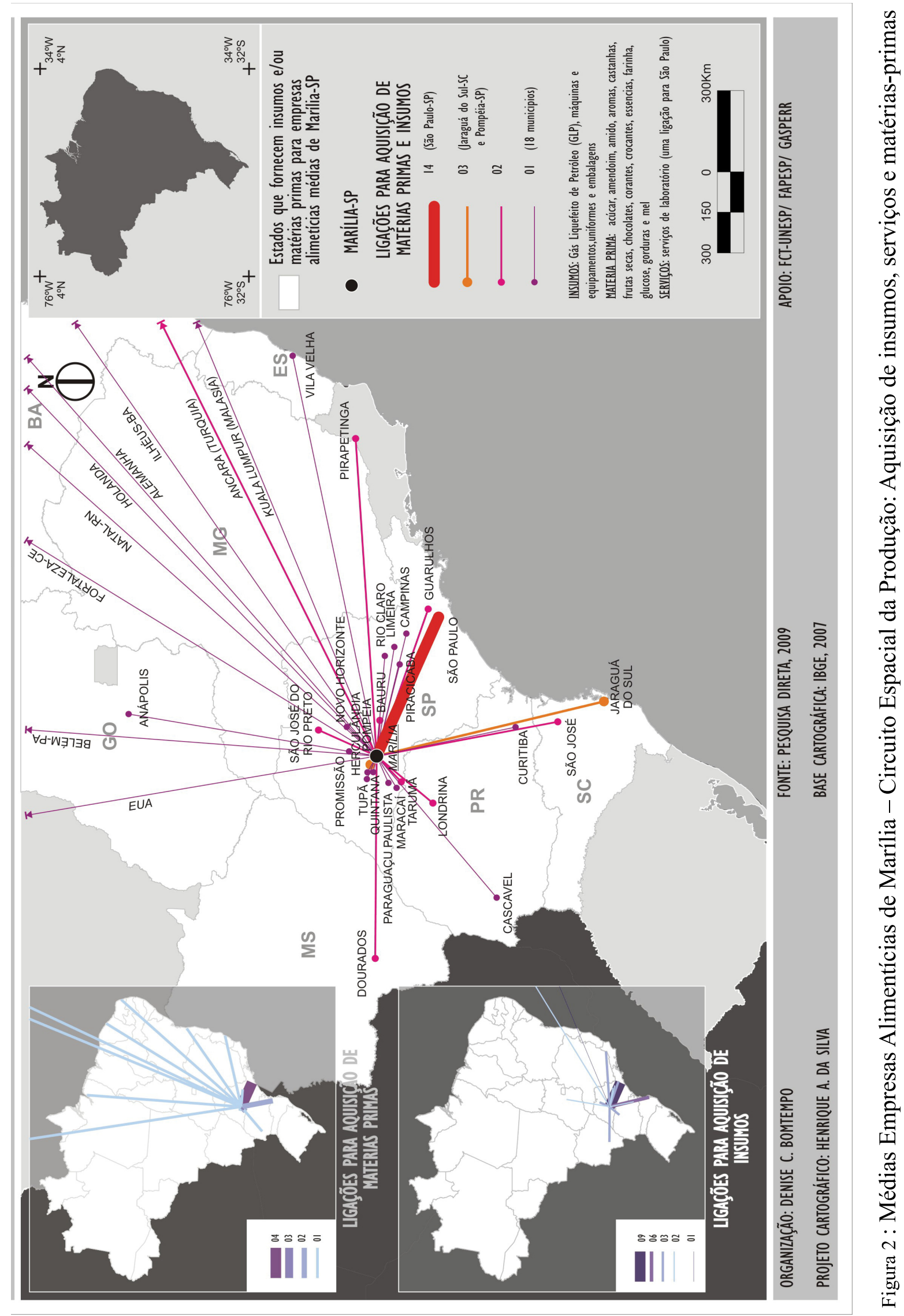


estados destacam-se Ilhéus/BA (chocolate); Belo Horizonte/MG (leite em pó); Jaraguá do Sul/SC (essências e corantes); Fortaleza/CE e Natal/RN (castanha de caju); Belém/PA (castanha-do-pará) e Cascavel/PR (farinha de trigo). 3) em âmbito internacional, temos a gordura vegetal que é comprada de Kuala Lumpur (Malásia) e as castanhas e frutas secas provenientes de Ancara (Turquia).

Se considerarmos somente a compra de embalagens, constatamos que as interações espaciais articulam Marília com São Paulo/SP, Guarulhos/SP, São José do Rio Preto/SP, Anápolis/GO, Dourados/MS, Pirapetinga/MG, Curitiba/PR, Londrina/PR e São José/SC.

Por sua vez, as empresas fornecedoras de uniformes estão localizadas na própria cidade de Marília, mas também em São Paulo/SP, Bauru/SP e São José do Rio Preto/SP.

No que concerne às máquinas e equipamentos, os lugares envolvidos no circuito produtivo são respectivamente: Marília/SP (que concentra 7,69\% das empresas fornecedoras), São Paulo/ SP (com 11,53\% das empresas), Limeira/SP (3,84\%), Campinas/SP (3,84\%), Bauru/SP (3,84\%) e Santa Catarina (3,84\%). As médias empresas, além de máquinas e equipamentos nacionais, também utilizam, no processo produtivo, máquinas importadas, em especial vindas dos Estados Unidos, Holanda e Alemanha. A assistência das máquinas é realizada por empresas subcontratadas de Marília, São Paulo e pelo próprio fabricante.

O transporte dos produtos é realizado por frota de caminhões da própria empresa $(7,69 \%)$ e por empresas terceirizadas de Marília (15,38\%). Os produtos fabricados pelas médias empresas são distribuídos na escala local por 11,53\% das empresas industriais; 23,07\% distribuem apenas no estado de São Paulo; 11,53\% fornecem para os estados de São Paulo, Paraná e Santa Catarina; 7,69\% distribuem para todos os estados do Brasil e 15,38\% realizam exportações para países da América do Sul, Estados Unidos, países da Europa Ocidental, países da África, Japão, China e Índia.

De acordo com informações obtidas durante a pesquisa de campo, há cinco anos que as médias empresas industriais alimentícias contratam empresas subcontratadas para a realização de serviços de assessoria jurídica, transporte de cargas, portaria; vigilância e sistema de segurança, seleção e treinamento de mão de obra e limpeza e conservação predial. Todos esses serviços são realizados por firmas localizadas em Marília, e os serviços de alimentação de funcionários são oferecidos por uma empresa prestadora de serviços de Campinas/SP. Por fim, o serviço de consultoria em informática é realizado por uma empresa terceirizada de Joinville/SC.

O destino da produção geralmente envolve pequenos estabelecimentos comerciais e também redes de hipermercados e supermercados atuantes no território brasileiro e em outros países. Para expor seus produtos nesses estabelecimentos, articulados de maneira direta ao circuito superior da economia urbana, as empresas tiveram que se reestruturar, principalmente a partir de uma reorganização das suas estratégias de gestão. Também ocorreu incorporação de novas máquinas ao processo produtivo, para produzir mercadorias mais competitivas, e houve investimentos em novas embalagens e no lançamento de novas linhas de produtos, respeitando princípios básicos de competitividade impostos por uma normatização de padrões internacionais.

Em síntese, as empresas industriais alimentícias de padrão médio instaladas em Marília apresentam mais heterogeneidade no que diz respeito ao grau de articulação econômica e urbano regional. Temos unidades produtivas que atuam em âmbito local, mas também firmas que configuram amplos circuitos produtivos. De uma maneira geral são interações que articulam múltiplas escalas, tanto em estabelecimentos do circuito superior como inferior da economia urbana.

\section{As grandes empresas industriais: o caso da Dori Alimentos LTDA}

Como exemplo para a análise dos circuitos espaciais da produção e círculos de cooperação das grandes empresas de alimentos em Marília, selecionamos a Dori Alimentos LTDA, exatamente porque representa um investimento de origem local que cresceu gradativamente enquanto empresa produtora de balas e confeitos de amendoim. Hoje, além desses produtos distribuídos em escala nacional e internacional, a Dori também é líder na produção de pirulitos, gomas e granulados. 
A empresa iniciou suas atividades no ano de 1967, sob a responsabilidade de Doraci dos Santos Spila, que fabricava pipoca doce com a marca Guri. No ano de 1970, foi registrada na Junta Comercial do estado de São Paulo e no ano de 1976, deixou de funcionar na casa da proprietária, transferindo-se para um galpão de 500 metros quadrados. A partir de 1986, com a inserção de um sócio empreendedor (João Baptista Barion), mudanças importantes aconteceram e a empresa passou a produzir num ritmo fordista, ampliando o volume de produção e o mercado consumidor.

Desde então, as mudanças tornaram-se substanciais, a começar pela especialização da produção (confeitos de amendoim doce e salgado, gomas, balas, pirulitos e confeitos de chocolate), e também pelos novos investimentos (aquisição de máquinas e equipamentos).

Atualmente, a matriz da empresa e a unidade produtiva de Marília estão instaladas no Distrito Industrial Santo Barion, no norte da cidade. Compreende um complexo de produção e gestão de cerca de $23.000 \mathrm{~m} 2$ de área construída. O total de funcionários, no ano de 2009, era de 1.129, sendo que na fábrica eram empregados 653 trabalhadores e nos setores de apoio 476 funcionários.

As linhas de produção existentes na unidade de Marília são confeitos de amendoim e chocolate, chocolate granulado e pastilhas, balas e gomas de amido. Ainda, na matriz estão centralizadas as atividades de pesquisa e desenvolvimento, gestão, propaganda e marketing, o setor comercial e os setores de exportação e recursos humanos.

Desde 1986, a Dori possui, no Distrito Industrial do Jardim Santa Antonietta de Marília, uma unidade cerealista que realiza as atividades de beneficiamento e armazenamento do amendoim. A cerealista possui uma área de $42.000 \mathrm{~m} 2$, sendo $8.300 \mathrm{~m} 2$ de área construída. Conta com 135 funcionários, três trabalham no setor administrativo, 20 no setor de apoio e 111 no beneficiamento do amendoim. Atua em parceria com produtores rurais e outras cerealistas da cidade de Marília e municípios próximos para garantir o fornecimento do amendoim, uma das principais matérias-primas utilizadas pela empresa.

Em continuidade aos investimentos, no ano de 1989, a Dori Alimentos LTDA adquiriu uma empresa de balas na cidade de Rolândia, no Paraná. Atualmente, a área total desta unidade é de $46.000 \mathrm{~m} 2$ e a fábrica conta com $14.000 \mathrm{~m} 2$ de área construída. Trabalham, em Rolândia, 870 funcionários, sendo 668 no processo produtivo, $169 \mathrm{em}$ setores de apoio e 33 no setor administrativo. Essa unidade é responsável pela produção de balas duras, mastigáveis, recheadas, chicletes e pirulitos (duros, recheados e mastigáveis). Os produtos fabricados em Rolândia, destinados à exportação, saem da unidade em direção ao porto de Santos. Todavia, os que atendem ao mercado interno são enviados ao Centro de Distribuição da Dori, localizado na cidade de Marília.

O Centro de Distribuição (CD) da empresa localiza-se em Marília. Ele foi inaugurado no ano de 2003. A produção da unidade de Marília e Rolândia é enviada ao CD, que se localiza no distrito industrial do Jardim Santa Antonietta. Sua área total é de $111.000 \mathrm{~m} 2$ e a área construída é de apenas $9.500 \mathrm{~m} 2$. No CD são empregados 52 funcionários, sendo que 42 atuam no setor de logística e 10 no setor administrativo. O CD de Marília é responsável por controlar a produção das duas fábricas e por distribuir os produtos para todo o território brasileiro. As vendas para o mercado externo são controladas pelo setor de exportação (criado em 1995), localizado na unidade gestora da empresa em Marília. Ainda o CD é encarregado por enviar mercadorias ao CD filial de Fortaleza/CE, fundado em 2001, antes mesmo do CD de Marília.

A filial de distribuição da Dori em Fortaleza localiza-se as margens da Rodovia Federal BR-116, entre os km 12 e 13. O galpão possui $540 \mathrm{~m} 2$. De acordo com o gerente da Dori Alimentos LTDA de Fortaleza/CE, a central de distribuição entrou em funcionamento no ano de 2001. Possui cinco funcionários, entre os quais um gerente, encarregados de limpeza e carga/descarga, o responsável por recebimento e expedição de produtos e dois vendedores. Além dos funcionários diretos, a empresa possui um estagiário e um vendedor terceirizado.

O CD da Dori filial de Fortaleza/CE iniciou suas atividades distribuindo 25 toneladas de produtos por mês, mas atualmente esse número é de 150 toneladas de produtos/mês distribuídos no estado 
do Ceará. Os vendedores atuam em três regiões (Quixeramobim, Sobral e Região Metropolitana de Fortaleza). Eles realizam suas vendas via micro-computadores e repassam os pedidos para o CD Fortaleza, que por sua vez, os enviam para o CD Central de Marília, por via de um sistema computacional desenvolvido especificamente para a empresa. Os clientes do estado do Ceará recebem os produtos até cinco dias após o processamento dos pedidos.

O transporte dos produtos de Marília até Fortaleza é feito pela Rodovia BR-116. De acordo com o gerente, os funcionários e vendedores da Dori assistem a palestras que são proferidas por ele, que constantemente viaja para Marília, a fim de participar de cursos e reuniões na matriz da empresa. De acordo com o responsável, a instalação da filial de distribuição em Fortaleza ocorreu por vários motivos: Primeiro, por se tratar de uma região (Nordeste) que tem ampliado o nível do consumo nos últimos anos; Segundo, para diminuir os custos, pois a carga tributária do estado do Ceará é menor e, por isso, as despesas com o deslocamento das mercadorias são reduzidas.

Além do $\mathrm{CD}$ filial Fortaleza/CE, a Dori possui centros de representação comercial distribuídos nas cinco regiões brasileiras, são elas: Norte (nos estados do Acre, Amazonas, Pará e Rondônia); Nordeste (nos estados da Bahia, Maranhão, Pernambuco, Piauí e Rio Grande do Norte); Sudeste (Espírito Santo, Minas Gerais e Rio de Janeiro); Centro-Oeste (Distrito Federal, Goiás e Mato Grosso do Sul) e Sul (Paraná, Santa Catarina e Rio Grande do Sul) (Figura 3).

$\mathrm{Na}$ escala internacional, verificamos que as relações comerciais realizadas pela Dori, ocorrem, sobretudo, entre os países do continente americano, africano e asiático. A empresa possui representantes de distribuição no continente africano (nos países de Angola, Cabo Verde, Camarões, Congo, Costa do Marfim, Gana, Gâmbia, África do Sul, Guiné, Guiné Bissal, Quênia, Mali, Madagascar, República Democrática do Congo, Senegal e Serra Leoa); no continente europeu (nos países de Portugal e Alemanha); na Oceania (Austrália, Formosa e Ihas Fiji); no continente americano (nos países da Argentina, Colômbia, Canadá, Costa Rica, Chile, El Salvador, Estados Unidos, Haiti, Porto Rico, Uruguai e Venezuela); e ainda na Ásia e no Oriente Médio (nos países dos Emirados Árabes, Hong Kong, Israel, Japão e Jordânia).

Atualmente, $25 \%$ da produção são exportados. O principal comprador dos produtos da Dori no exterior é a rede americana Wal Mart. Os produtos são destinados para abastecer as lojas da rede localizadas nos Estados Unidos e nos países europeus. Na escala do território brasileiro, a empresa investigada vende seus produtos a empresas articuladas tanto ao circuito superior da economia urbana, tais como atacadistas, distribuidoras, redes de hipermercados, supermercados e pequenos estabelecimentos comerciais, como também empresas vinculadas ao circuito inferior, como pequenos mercados, padarias, lojas de produtos importados baratos etc. (Figura 4).

O fluxo de informações e as ordens de comando administrativo são feitos por meio de um sistema intranet, elaborado especificamente pela Dori. Todos os funcionários que ocupam posições estratégicas na empresa, como os diretores, supervisores e encarregados, possuem acesso ao sistema na área em que é responsável. Há uma articulação entre os setores da empresa e isso é possível devido às reuniões periódicas e também ao sistema informacional que permite que os lugares relacionados ao circuito espacial produtivo da Dori, por um lado, informem as necessidades vinculadas à atividade desenvolvida $\mathrm{e}$, por outro, recebam as normatizações a serem cumpridas.

De acordo com informações obtidas durante a pesquisa de campo, as máquinas utilizadas no processo produtivo são fabricadas no Brasil (SP e PR) e importadas de países como Alemanha, Itália e Estados Unidos. A manutenção das máquinas e equipamentos é feita internamente, porém, se for preciso, os representantes das empresas no Brasil são acionados para prestarem serviços.

A empresa é dividida em setores de acordo com a linha de produto fabricada. Os setores são alimentados por intermediários e subsetores. Na fábrica ainda existe o empacotamento, setor de armazenamento de produtos, expedição e carga e descarga. Cada seção corresponde a uma minifábrica em que são realizados todos os processos de fabricação e direcionado ao setor de empacotamento. Esse último, dividido em três partes, é muito importante, pois ele registra as normatizações exigidas pelos órgãos de fiscalização e controle alimentar. 


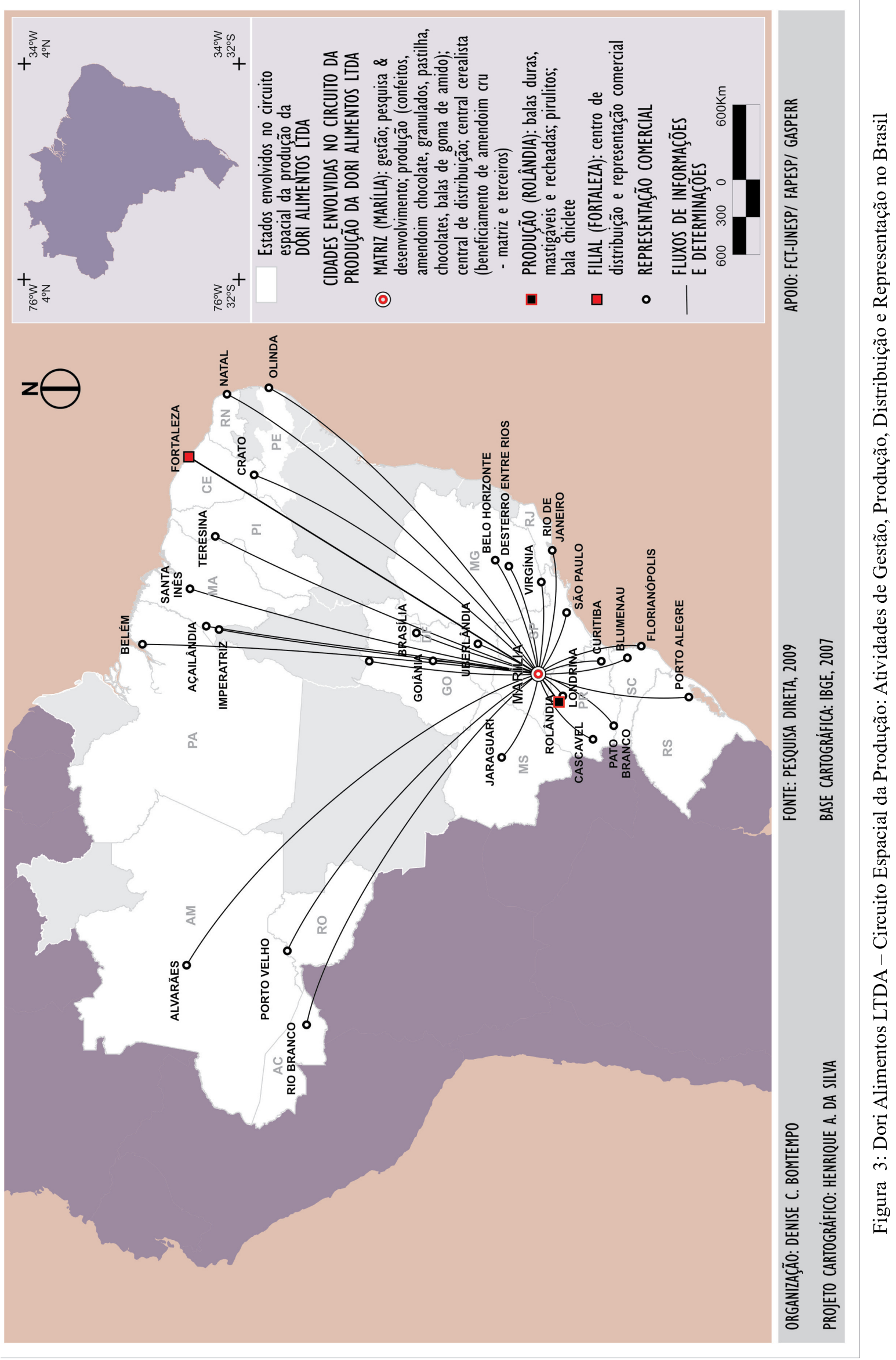



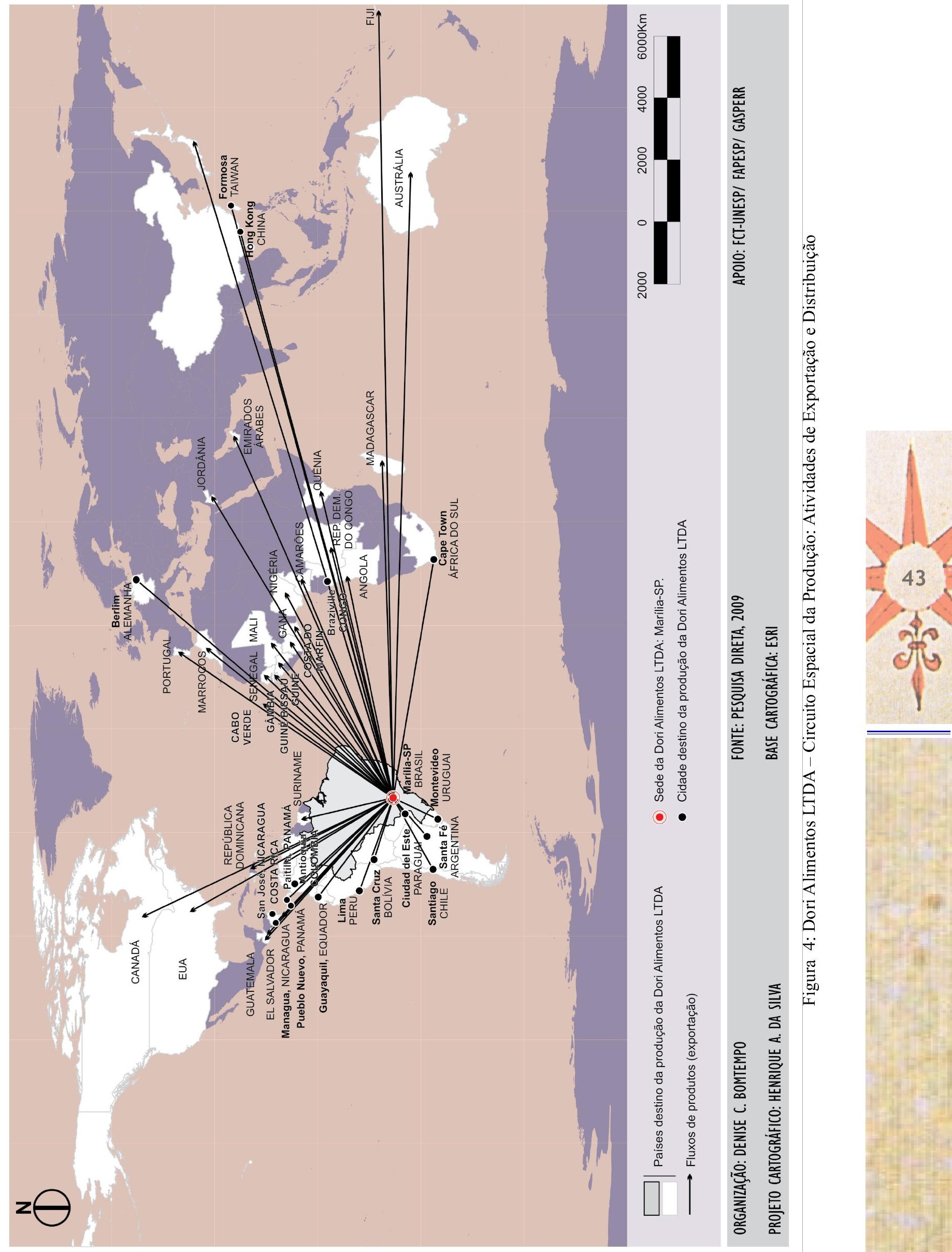
Na unidade produtiva da Dori de Marília, os turnos de trabalho são dois, das $6 \mathrm{~h}$ às $14 \mathrm{~h}$ e das 14:35 às $23 \mathrm{~h}$. Aos sábados, a fábrica funciona apenas quatro horas e, durante a jornada, o horário para refeições é de 32 minutos. Os setores da fábrica são liberados um a um para almoço ou jantar. A remuneração do trabalhador da fábrica é de $\mathrm{R} \$ 750,00$ para os auxiliares de produção e $\mathrm{R} \$ 930,00$ para os operadores de máquinas. Os trabalhadores são inseridos no programa de participação de lucros, o equivalente a um $14^{\circ}$ salário por ano. A empresa oferece vale transporte, plano de saúde (médico e odontológico) e cesta básica (comprada em rede de supermercado de Marília) e têm articulação com as instituições locais ligadas à atividade industrial, a exemplo da Associação das Indústrias Alimentícias de Marília (ADIMA). Na escala estadual e nacional é integrante da Associação Brasileira das Indústrias de Alimentação (ABIA) e da Associação Brasileira das Indústrias de Chocolates, Cacau, Amendoim, Balas e Derivados (ABICAB).

A Dori Alimentos LTDA, assim como as médias e grandes empresas alimentícias de consumo final de Marília, articulam os lugares envolvidos no circuito espacial produtivo de maneira multiescalar. Na escala local, além das atividades realizadas diretamente pela empresa, percebemos que a prática industrial permite com que outros setores da economia sejam dinamizados, tais como o de serviços. As funções realizadas por empresas subcontratadas na Dori são, respectivamente, limpeza e conservação predial (restaurante e área administrativa). A prestadora de serviços é de Marília, assim como a de vigilância; o restaurante é administrado por uma empresa de Campinas/SP; o transporte de mercadorias realizado por motoristas autônomos que residem em Marília; a assessoria jurídica e contábil é realizada por profissionais da própria Dori e por empresas terceirizadas da cidade.

A Dori Alimentos LTDA adquire majoritariamente, matéria-prima de fornecedores do estado de São Paulo, localizados na Região Administrativa de Marília, em municípios como Quintana, Tupã, Herculândia (amendoim), e em municípios de outras Regiões Administrativas do estado, tais como Jaú e Ribeirão Preto (açúcar), Campinas (glicose a administração de restaurante interno), Boituva (molho de soja) e São Paulo (essências, embalagens e serviços de tradução). De acordo com as informações obtidas, somente um município localizado fora do estado de São Paulo pertence ao circuito espacial da produção da Dori como fornecedor de matéria-prima, isto é, Ilhéus na Bahia, que fornece amido de cacau.

As atividades de representação e distribuição não estão localizadas em pequenas cidades, mas em metrópoles, como Fortaleza/CE, Belo Horizonte/MG, Rio de Janeiro/RJ, São Paulo/SP, Curitiba/PR, Porto Alegre/RS, entre outras. Portanto, o papel que a cidade média, a partir das atividades econômicas desenvolvidas, possui na divisão territorial do trabalho e na rede urbana em que está inserida é majoritariamente de intermediação. No entanto, essa intermediação não é apenas com os lugares próximos, pelo contrário, a proximidade é sentida a partir da configuração de redes topológicas que articulam e aproximam as parcelas do espaço de acordo com as atividades econômicas desenvolvidas.

Além das funções de intermediação, percebemos que, por ser sede de grandes empresas, as atividades de comando atreladas a esse ramo industrial são realizadas também na escala da cidade média, não somente nas atividades ligadas ao circuito produtivo, mas em outras associadas ao poder público no âmbito local, estadual e federal. Isso de fato, define as novas escalas que determinam o uso do território no período da globalização, pois as metrópoles mencionadas, a partir das atividades comerciais e distribuição, participam do circuito espacial produtivo da Dori como pontos. Por sua vez, a cidade de Marília onde se localiza a sede da empresa, é que determina o uso do território conforme seus interesses, obviamente de acordo com as possibilidades de ampliar sua margem de lucro no mercado de competição global. Para tanto, possui uma política estratégica, investe em desenvolvimento tecnológico, de novos produtos e processos, aquisição de máquinas e equipamentos e concorre na escala global com empresas do mesmo segmento para fornecer seus produtos a grandes redes de supermercados e hipermercados. 


\section{CONSIDERAÇÕES FINAIS}

Além das múltiplas escalas articuladas ao circuito espacial da produção e aos círculos de cooperação do ramo alimentício de consumo final de Marília, percebemos que existem dinâmicas complexas que precisam ser lidas e entendidas de maneira renovada no âmbito da geografia urbana e econômica. Assim, analisar a industrialização das cidades médias parece ser um caminho para entender o novo na escala do território brasileiro.

Gostaríamos de reforçar que, mediante o "mapeamento" do circuito espacial da produção e dos círculos de cooperação das indústrias alimentícias de consumo final instaladas em Marília, conseguimos entender o real conteúdo industrial dessa cidade no período técnico-científico. Constatamos que as pequenas empresas contribuem para que a cidade continue seu papel de intermediação nas escalas local e regional. Em contrapartida, as grandes e médias empresas industriais, que adotaram dimensões da reestruturação produtiva, permitem que Marília tenha uma ampliação de seus papeis na rede urbana, bem como na divisão territorial do trabalho.

Outro elemento referente às empresas industriais alimentícias de Marília, é que elas distribuem seus produtos tanto em empresas associadas ao circuito inferior da economia urbana, sobretudo as micro e pequenas, como ao superior. No caso da inserção no circuito superior da economia urbana é preciso cumprir inúmeras normatizações relacionadas à produção de alimentos pelas agências reguladoras. No entanto, as estratégias de venda se diferenciam de acordo com o padrão do estabelecimento.

Marília, por ser sede de grandes empresas, centraliza o capital do ramo produtivo industrial alimentício de consumo final e desempenha papeis de gestão, pesquisa e desenvolvimento, distribuição e produção. Ela contribui também para a elaboração de normas junto às instituições articuladas diretamente ao ramo alimentício e ao poder público.

Assim, podemos concluir que na divisão territorial do trabalho, essa cidade, por concentrar unidades produtivas de grupos empresariais de capital nacional e transnacional, pode ser considerada um ponto que contribui na configuração do ciclo de reprodução do capital, mas também pode ser caracterizada como um nó, pois centraliza o próprio capital por sediar grandes empresas.

No caso estudado, podemos afirmar que a aglomeração urbana forneceu condições gerais favoráveis para o desenvolvimento de um ramo industrial e que, ao longo do tempo, essa atividade contribuiu para o surgimento de uma especialização produtiva territorial, bem como para a ampliação das funções desempenhadas pela cidade na divisão territorial do trabalho e na rede urbana em que está inserida e que mantém relações.

Desvendar o conteúdo industrial de Marília permitiu, entre outras características, afirmar que é preciso, no período técnico-científico, entender o conteúdo do território a partir das atividades econômicas industriais desenvolvidas também na escala das cidades médias e pequenas, pois elas denotam os processos e as dinâmicas em curso no território.

\section{AGRADECIMENTOS}

À Fundação Cearense de Amparo à Pesquisa do Ceará pela conceção de Bolsa em Desenvolvimento Científico Regional (DCR/CNPq/Funcap).

\section{REFERÊNCIA BIBLIOGRÁFICA}

ANUÁRIO da Associação Brasileira de Indústrias de Alimentos, 2009, 2010.

ARROYO, Maria Mónica. Território Nacional e mercado externo: uma leitura do Brasil na virada do século XXI. Tese de Doutorado defendida no Programa de Pós-Graduação em Geografia Humana da FFLCH/ USP. São Paulo: FFLCH, 2001.

ARROYO, Maria Mónica. Novos paradigmas: a economia invisível dos pequenos. In: Le monde diplomatique. Edição Brasileira, Ano II, no. 15. Out., 2008. (p. 30 a 31). 
BELTRÃO SPOSITO, Maria Encarnação; ELIAS, Denise; SOARES, Beatriz Ribeiro; MAIA, Doralice Sátyro; GOMES, Edvânia Tôrres Aguiar. O estudo das cidades médias brasileiras: uma proposta metodológica. In: BELTRÃO SPOSITO, Maria Encarnação (Org.). Cidades médias: espaços em transição. São Paulo: Expressão Popular, 2007.

BENKO, Georges. Economia, espaço e globalização. São Paulo: Hucitec, 1996.

BOMTEMPO, Denise Cristina. Cidades médias, aglomeração industrial e circuito espacial da produção de alimentos. Relatório de qualificação de doutorado, defendido no Programa de Pós-Graduação em Geografia da FCT/UNESP Presidente Prudente. FCT/UNESP/PPGG/Presidente Prudente, agosto de 2010. CHESNAIS, François. A mundialização do capital. São Paulo: Xamã, 1996.

ELIAS, Denise de Souza. Agricultura e produção de espaços urbanos não metropolitanos: notas teórico-metodológicas. In: BELTRÃO SPOSITO, Maria Encarnação(Org.). Cidades médias: espaços em transição. São Paulo: Expressão Popular, 2007.

FUNDAÇÃO SEADE - Ministério do Trabalho e Emprego - MTE. Relação Anual de Informações Sociais - RAIS.

JORNAL DIÁRIO DO PERNAMBUCO. "Kraft Foods inaugura nesta terça sua primeira fábrica no Nordeste". Disponível em http://www.diariodepernambuco.com.br/economia/nota.asp?materia=20110502201254. Acesso 16/7/2011.

MARTINELLI JÚNIOR, Orlando. A globalização e a indústria alimentar: um estudo a partir das grandes empresas. Marília - UNESP - Marília Publicações; São Paulo: FAPESP, 1999.

MOURÃO, Paulo Fernando Cirino. A industrialização do Oeste Paulista: o caso de Marília. Presidente Prudente: PPGG/FCT/UNESP (dissertação de Mestrado), 1994.

RELAÇÃO ANUAL DE INFORMAÇÕES SOCIAIS - RAIS. Base de dados estatísticos. Vários anos. Brasília: RAIS, 2010. CD-ROM.

REVISTA SUPER VAREJO. "As cinco mais". APAS: Agosto de 2005 (http://www.portalapas.org.br).

SANTOS, Milton. Circuitos espaciais da Produção: um comentário. In: SOUZA, Maria Adélia A. de (Org.). A construção do Espaço. São Paulo: Nobel, 1986.

SANTOS, Milton. Por uma outra globalização - do pensamento único à consciência universal. $2^{\mathrm{a}}$ ed. Rio de Janeiro: Record, 2000.

SANTOS, Milton. O espaço dividido: os dois circuitos da economia urbana. São Paulo: EDUSP, 2004.

SANTOS, Milton. Economia Espacial. São Paulo: EDUSP, 1979/2003.

SANTOS, Milton. A urbanização brasileira. São Paulo: EDUSP, 2005.

SANTOS, Milton. Metrópole corporativa e fragmentada: caso de São Paulo. São Paulo: EDUSP, 2009,

SANTOS, Milton \& SILVEIRA, Maria Laura da. Brasil: território e sociedade no início do século XXI. Rio de Janeiro: Record, 2001.

SILVEIRA, María. Laura. Metrópolis brasileñas: un análisis de los circuitos de la economía urbana. Revista Eure. Santiago de Chile, V. XXXIII, No. 100, p. 149-164. Diciembre, 2007.

SOBARZO, Oscar. As cidades médias e a urbanização contemporânea. Revista Cidades. Presidente Prudente: Grupo de Estudos Urbanos, v. 5, no. 8, p. 277-292, 2008.

SPOSITO, Eliseu Savério. Reetruturação produtiva e reestruturação urbana no Estado de São Paulo. In: IX Coloquio Internacional de Geocrítica - Los problemas del mundo actual. Soluciones y alternativas desde la geografía y las ciencias sociales. Anais... Porto Alegre: Universidade Federal do Rio Grande do Sul, 28 de maio a 1 de junho de 2007.

Trabalho enviado em junho de 2012

Trabalho aceito em agosto de 2012 